\title{
Repetition in Willa Cather's Early Writings: Clues to the Development of an Artist
}

\author{
Mona Pers \\ Uppsala University
}

"Willa Cather had so few things to write about that she had to use the same material over and over," is a complaint occasionally voiced by critical readers. The aim of this article is to suggest other explanations of the recurrence of characters, scenes, incidents, ideas, images and expressions in her works by showing where her habit of revising old material originated, and tracing its development, as well as to demonstrate how useful those "repetitions," in both her journalistic and fictional writings, are for those interested in studying the emergence of Willa Cather as a consummate master of style.

Even as a student at the University of Nebraska Willa Cather was a prolific contributor to the local papers for several years. Articles and reviews, unsigned or signed with various pen-names, some of them until recently unidentified, continue to be discovered by literary scholars. Not to deny her unusual capacity to write fast, and mostly well, her surprising productivity can in part be explained by the fact that she used the same material, with cuts, additions or rearrangements, more than once, often with months and years between dates of publication. The frequent recurrence of old material, slightly changed and often applied to new contexts, suggests not only that Willa Cather, contrary to what she later maintained, saved for years much of what she had written, but also that she may have kept the pieces she was pleased with arranged and filed in such a fashion that she could easily find whatever she needed from them in a hurry. Besides, an anecdote she was fond of relating indicates that she also had an exceptional memory of things she had once put down on paper. Asked to give a talk at a Women's Club meeting, she started to recite, almost word for word, 
an essay she had written about Carlyle half a dozen years earlier, when she had just turned seventeen. ${ }^{1}$

The fact that young Willa Cather often made her drama reviews serve more than one paper, sometimes with little or no changes in the text, has been of great help to scholars in establishing the authorship of unsigned pieces and in identifying new pen-names. In her more extensive articles featuring actors and actresses, too, she was apt to "borrow" long passages from one to include them in another, again with long time spans, sometimes, between dates of publication. This habit of hers may be exemplified by a review she wrote of Joseph Jefferson in Rip Van Winkle for the Pittsburgh Leader in 1896, and an article entitled "An Open Letter to Joseph Jefferson," published a couple of years later in the Lincoln Courier. From the Leader, Nov. 10, 1896:

How few histrionic characters there are that one really Ioves, anyway, how few of the revered cardinal virtues behind the footlights for which we really care in our heart of hearts. Some we admire and some amuse us; but feel a personal delight in them, ah, that is another matter! And yet the world has loved this kindly improvident dramdrinking Dutchman for more than a quarter of a century and has never wavered in its loyalty. Only an actor who sees deeply and far into life, who is ripe in judgment and gentle by nature, who loves the world for its own value, weak and wilful and inconsistent as it is, could ever endear the character to us so. ${ }^{2}$

From the Courier, Dec. 2, 1899:

How few historical creations, sir, have ever really installed themselves in our affections! How few of those revered cardinal virtues behind the footlights are really dear to us in our heart of hearts. Some amuse us, some we admire; but toward how few do we feel the warmth of a personal affection; yet for nigh upon half a century this improvident, dream-drinking [sic] Dutchnnan has been beloved by the whole English-speaking world. Only an actor ripe in judgment, rich in sympathy, gentle by nature and very lovable himself could so have endeared such a character to us. (W\&P, p. 685)

An examination of those two early journalistic pieces gives us some hints as to the direction Willa Cather's artistic development was to take. As is to be expected, the parts she decided to use unchanged a second time show a closer similarity to her mature style of writing than the parts she decided to discard. Even at this early stage it is possible to trace the seed of the writer's slowly growing dislike of abstractions, which was to develop into downright aversion in later years. It is significant that the words she kept in the second extract above are primarily of the colorful, down-to-earth, concrete kind with exact meanings that are the well-known trademark of the mature artist's carefully worked out vocabulary. The phrases and 
expressions she leaves unaltered are the ones that read most easily and naturally, that seem to have caught the cadence of a welltrimmed spoken language. As her writing developed into art, this type of harmoniously well-balanced phrase is predominant, probably constituting a major reason for the generally adopted opinion that her prose has a musical quality of exquisite purity. For the student of the author's stylistic as well as emotional growth, the alterations, cuts, and elaborations in her revised texts should be of great interest. Thus one can draw the conclusion from comparisons between early pieces such as the ones cited above, that Willa Cather started early to work towards the goal she later set up in her essay, "The Novel Demeublé": "Art is to simplify."3 It is obvious that, in the three years that elapsed between the two Rip Van Winkle articles, her language grew less wordy and less exclamatory. The following two quotations, again taken from those same articles, show even more clearly the modest beginning of the young writer's strivings away from an overly elaborate mode of expression towards a simpler and more lucid style. In 1896 she wrote

Only half awake in this indolent, happy-go-lucky, irresponsible old Dutchman is the same strain of blood which made his countrymen ... he has the fresh, childlike perceptions that have made poets of so many of the world's vagabonds. (WEP, p. 423)

Three years later, she had tightened her language, and the result was that her observation gained in clarity as well as in "punch":

Only half awake in this tippling Dutchman are those fresh, childlike perceptions that have made poets of so many of the world's vagabonds. (W \&P, p. 685)

Willa Gather's fondness for long-winding sentences is slowly tapering off - she endeavors to break them up into smaller units or make them shorter by merely substituting "le mot propre," in this case "tippling," for that rather cumbersome string of descriptive adjectives "indolent, happy-go-lucky, irresponsible old." These same articles contain several good examples of simplified sentence structures that give to her ideas a more direct presentation. Thus her decision to change

There is no scene on the stage today half so weirdly poetic as that third act upon the moonlit Catskill, with its long, trying monologue, done so gracefully and naturally. ... (WEP, p. 423)

into

No scene has ever been made more weirdly poetic than that on the moonlit Catskills, with its long, trying monologue so gracefully and naturally delivered. (W\&P, p. 685) 
resulted in a more clear-cut statement stripped of distracting qualifications such as "on the stage today" and "third act."Changing the opening of the sentence also made her statement more dynamic. The forceful openings of key phrases and paragraphs she gradually developed into one of the most attractive features of her prose style. They greatly enhance the vigor of her mature mood of expression.

Parallel with her work as a journalist, Willa Cather wrote fiction in her spare moments. It is therefore not surprising that, now and then, material previously used in articles turns up again in her fictional works. Such is the case, for instance, in two of her short stories, "A Resurrection" (1897) and "Eric Hermanson's Soul" (1900). ${ }^{\mathbf{4}}$ The setting of the former story is Brownville, a sleepy little town by the Mississippi river also described in a reportage, "Brownville," made a couple of years before, and again in a feature article called "The Hottest Day I Ever Spent," published in a literary magazine three years after the short story. ${ }^{5}$ The following extracts drawn from those journalistic pieces, probably among the longest sentences Willa Cather ever wrote, are identical except tor the the changes made in the first third:

From "Brownville":

Yet even now one can sit on the upper verandah and look down over the dark streets with their broken, ragged outline of falling and fallen buildings and conjure up memories of the time when those dirty,
From "The Hottest Day": That night we sat on the verandah looking down the desolated streets

conjuring up memories of the time when those dark,

[In both versions:]

broken, glass fronts were ablaze with light, when the streets were full of ox teams and loaded wagons bound for Pike's Peak, and the teamsters were singing and twanging their banjos in front of the Lone Tree saloon, and on that same verandah the cabin passengers and wealthy traders sat and smoked and looking out over the river watched their steamers lying at the wharf, and listened to the hoarse whistle of the boats as they came around the bend in the bluffs, with their dancing lights and train of sparlss and cinders blown hack into the darkness. . . . ( $W \& P$, pp. 108-9 and 781)

In the later version, the opening of the presentation is more straightforward, and the exchange of "one" for "we" establishes a more personal tone. The writer's budding predilection for clear-cut contrasts is likewise discernible in these Brownville texts. She discards, for instance, the adjective "dirty" in favor of the word"dark," more appropriate because it is the natural contrast to the following 
"light," and because it underlines the desolate atmosphere of the place.

In "A Resurrection" there is a similar description of the protagonist reminiscing about old times in front of the Lone Tree saloon when he

watched the steamers swing around the bend at night, glittering with lights, with bands of music playing on their decks and the sparks from the smokestacks blowing back into the darkness. (CSF, p. 430)

But now the lights are gone, and the town is all but deserted. Between the descriptions of the Brownville inhabitants in the short story and the one given in the earlier article there is more of a word resemblance than in the account of the bustling activity on the river. In "Brownville" she declares that

The present population of Brownville is composed mostly of "river folks, " and a nondescript people who have come up the river from nowhere. . . (they) bought the big housesfor a song, and cut down the great cedars and oaks in the yard for firewood, and ploughed up the terraces for a potato patch, and are contented after the manner of their kind. (W\&P, p. 109)

In "A Resurrection," the description is basically the same, although the language is slightly tighter:

The sturdy pioneers moved away and the "river rats" drifted in, a nondescript people who came up the river from nowhere and bought u $p$ the big houses for a song, cut down the tall oaks and cedars in the yards for firewood, and plowed up the terraces for potato patches and were content after the manner of their kind. (CSF, pp. 430-31)

Between the two texts, there is a change of tone, however. The ironical touch in the first version is replaced, in the second, by a more unveiled indignation and a sense of loss. This change is a foreshadowing of what was to happen to the mood expressed in Willa Cather's mature works. The ironical and satirical strains, strongly pronounced in her earliest writings, both journalistic and fictional, gradually wore off, and towards the end of her literary career, almost disappeared.

The sentences extracted from "A Resurrection" disclose a growing concern for word order, indicating the writer's heightened sensitivity to rhythm and cadence. By changing, in the passages cited above, "the great cedars and oaks" to "the tall oaks and cedars" she created a more musical and harmonious word combination. The replacement of "great" by "tall," in the same sentence, exemplifies another trend in her artistic development, i.e. her increasing dislike of vague, diluted adjectives. 
Because of Brownville's lazy, degenerate inhabitants, Willa Cather expressed little hope for the future of that poor dilapidated town. In her article, she freely gives vent to her scorn for them:

The only ambition the y are ever guilty of is that vague yearning which stirs in the breasts of all river boys, to go down the river into the big world some day, clear down, as far as the river goes. But they never go. They build a skiff and live on catfish and drifitwood and play their banjos. (WEP, p. 109)

Although Martin, the protagonist of "A Resurrection" is definitely of their kind, the author treats him more gently. She does not seem to hold him fully responsible for his irresponsible behavior, but uses his background and childhood experiences to furnish an explanation, maybe even an excuse, of his reactions and behavior as an adult:

The first ambition he was ever guilty of was that vague yearning which stirs in the breasts of all river boys, to go down the river sometime, clear down as far as the river goes. (CSF, p. 431)

This sentence is preceded, not, as in the article, followed by the following remark: "They each have their skiff and burn driftwood and subsist on catfish and play their banjos ..." (CSF, p. 431). This change gives more emphasis to the central role the river played in the lives of these boys. By first describing how important the river was for the Brownville boys in general, and then returning to it to explain the special significance it had for Martin's development, the author deepens the reader's understanding of the river's deceptive lure,

For a study of repetitions and revisions in the works of Willa Cather, her many metaphors and similes offer rewarding material; once she had found an image she lilted she did not hesitate to use it several times. It seems that occasionally she grew dissatisfied with the way she had formulated an image and wanted to give it a second try. This may have been the case with her comparisons of Brownville with Pompeii, which she included in both of her articles as well as in her short story. "Today the town is a little Pornpeii buried in bonded indebtedness" (W\&P, p.109) remains practically unchanged in "A Resurrection" : "the village became a little Pornpeii buried in bonded indebtedness" (CSF, p. 430), while, in its final application, the image has been submitted to changes that make the comparison more relevant: "we thought we had unearthed a little Pompeii" ( $W \mathcal{E}^{2} P$, p. 779).

It seems that Willa Cather considered certain images she had 
introduced too compressed, and when she saw fit to use them again, she decided to elaborate them for the purpose of clarification. Such was probably the case with the following analogy between Brownville and de Musset. Her observation that "The town calls to mind that scathing epigram which Heine applied to de Musset, 'A young man with a brilliant past."' ( $W \& P$, p. 109) grew, in "A Resurrection" into a more explicit statement:

No, the town has had a history, a brief, sad little history which recalls the scathing epigram that Herr Heine once applied to M. Alfred de Musset; it is a young town with a brilliant past. (CSF, p. 429)

Willa Cather's fascination with images is almost legendary. Her preoccupation with imagery leads me to suspect that her philosophy of life was not the fruit of theoretical reasoning, but rather made $u p$ of images, colorful pictures that suggested ideas to her mind. There are indications in her writings that the images she used to illuminate an idea in fact sometimes preceded that idea. She probably had pictures in store for which she sought the best possible use. This may have been the case with the following simile, first applied in one of her drama reviews: "Irving's Shylock is no more of a cynic than the child who kicks the door that pinched his fingers." 6 As she undoubtedly realized that she had not done full justice to this colorful image, she decided, the following year, to make use of it again in a new context, the short story "El Dorado: A Kansas Recessional" (1901), where the simile undeniably makes more sense: "When men are hurt they must have something to turn upon, like children who kick the door that pinches their fingers" (CSF, p. 303).

The development of her imagery, like her style as a whole, tends toward simplification. Two examples chosen from a great variety of statements establishing similarities Willa Cather had recognized between children and artists may serve to illustrate how slight changes of simplification could produce a phrase of better balance and easier flow. The rather cramped comment from "The Treasure of Far Island" (1902): "A child's normal attitude toward the world is that of the artist, pure and simple" (CSF, p. 275), is straightened out in The Song \& the Lark (1915), bringing about a notable improvement: "A child's attitude toward everything is an artist's attitude" (p. 551).7

In the majority of cases, Willa Cather manages to find a more suitable setting for her images as well as for her ideas the second 
time she tries. "Eric Hermanson's Soul" is an exception, however. In this story, the following reflection, advanced in an article written five years earlier, turns up again:

After all nature revenges herself. We cannot with impunity rise entirely above her any more than we can sink below her. She turned upon Jerusalem after a time just as she had turned upon Sodom. She revolted upon Saint Anthony in his desert just as she did upon Nero in his seraglio. That is why all particularly exquisite families have their black sheep at last. They may tame the tiger for centuries and think they have made a kitten of it, but in the hot blood of some descendant it breaks out sooner or later and cries, "I am here still, you cannot thwart me nor starue me nor tame me nor stultify me, I am here always, at the bottom of things; I made the world, I rule it and $I$ am its destiny. ...."

This passage was revised in "Eric Hermanson's Soul" in the following manner:

Cheat nature? Bah! One generation may do it, perhaps two, but the third-Can we ever rise above nature or sink below her? Did she not turn on Jerusalem as upon Sodom, upon St. Anthony in his desert as upon Nero in his seraglio? Does she not always cry in brutal triumph: "I am here still, at the bottom of things, warming the roots of life; you cannot starve me nor tame me nor thwart me; I made the world, I rule it, and I am its destiny. (CSF, p. 377)

In my opinion, this reflection is more to the point and more fully integrated in the article than in the story, where it fails to effectively support the theme. The ending of the love affairand this reflection upon the situation do not seem to say exactly the same thing. From a stylistic point of view, however, the version in the story is decidedly an improvement. The structure is tighter, and the tone more provocative, an effect created, for instance, by changing "She turned upon Jerusalem ..."into a question. By changing the word order in the last sentence she got rid of an unnecessary repetition. By changing the order of "Thwart, starve, tame" and dropping "stultify" she created a crescendo that could be sustained. There is plenty of proof, especially in Willa Cather's mature writings, that she willingly adhered to the classical rule of three.

So far, I have primarily dealt with such borrowings as Willa Cather made from her journalistic writings. There are, however, passages in her fictional works, too, that she saw fit to use again elsewhere. The following extracts, taken from her two Chinese short stories, "A Son of the Celestial" (1893) and "The Conversion of Sum Lo" (1900), depict the backgrounds of the two protagonists, Yung and Sum Chin, who are Chinese expatriates living on the American west coast. Very likely Willa Cather returned to her 
first Chinese story while planning the second, and then decided to include this material, practically unaltered, in her new story:

When he [Yung] was a boy he lived in Nanking, the oldest city of the oldest empire, where the great schools are and the tallest pagoda in the world rears its height of shining porcelain. There he had been educated, and had learned all the wisdom of the Chinese. He became tired of all that after awhile; tired of the rice paper books and of the masters in their black gowns, of the blue mountains and of the shadows of the great tower that fell sharp upon theyellow pavement in the glare of the sun. He went south; down the great canal in a red barge with big sails like dragon's wings. He came to Soutcheofou that is built upon the waterways among the hills of Lake Taihoo. There the air smelt always of flowers, and the bamboo woods were green, and the rice fields shook in the wind. There the actors andjugglers gather the year around, and the Mandarins come to find brides for their harems. For once a god had loved a woman of that city, and he gave to her the charms of heaven, and since then the maidens of Soutcheofou have been the most beautiful in the Middle Kingdom, and have lived but to love and be loved. There Yung dwelt until he tired of pleasure. (CSF, p. 525)

This passage thus turns up, with slight changes, more than six years later in "The Conversion of Sum Lo," probably written in a hurry to help fill the pages of a short-lived Pittsburgh magazine called the Library :

As $a$ boy he [Sum Chin] had dwelt in Nanking, the oldest city of the oldest Empire, where the great schools are, and where the tallest pagoda in the world rears its height $\delta$ shining porcelain. After he had taken the Eminent Degree of the Flowering Talent and been accorded an ovation by the magistrates of his town, he had grown tired of the place; tired of the rice paper books, and the masters in their black gowns, and the interminable prospect of the Seven Thousand Classics; of the distant blue mountains and the shadow of the great tower that grew longer and longer upon theyellow clay all afternoon. Then he had gone south, down the great canal on a barge with big red sails like dragons' wings. He came to Soutcheofou, that is built upon the waterways of the hills of Lake Taihoo. There the air smelt always of flowers, and the bamboo thickets were green, and the canals were bright as quicksilver, and between them the waving rice fields shimmered in the sun like green watered silk. There the actors andjugglers gathered all the year round. And there the mandarins come to find concubins. For once a god loved a maiden of Soutcheofou and gave her ths charms of heaven and since then the women of that city have been the most beautiful in the Middle Kingdom and have lived but to love and be loved. There Sum Chin had tarried. . . (CSF, p. 325)

It is, above all, in the exchange of crucial words that the improvements lie. Thus the information that the young man "had taken the Eminent Degree of the Flowering Talent" teases the imagination so much more than the rather flat "had been educated" does. It also fits the rest of this poetic description better. The observation that the shadow of the tower "grew longer and longer" instead of "fell sharply" stresses more effectively the restlessness of the young man. This is an early example of Willa Gather's skill in charging descrip- 
tive details with symbolic significance. By making the sails of the barge red rather than the barge itself, the writer made the boat more striking and exotic in appearance. The word "thicket" is more appropriate in connection with bamboo than "woods." The addition of canals to the scene, as well as the fuller description of the rice fields, finally, suffuse the picture with a luminous light that it did not have before. The play of light fascinated Willa Cather and dominates her rendering of both outdoor and indoor scenes more and more as her art matures. All the changes undertaken in the two passages above follow the general direction of Willa Cather's development as an artist towards a simpler, more concrete, exact, and yet increasingly picturesque mode of expression. Her prose moved steadily towards the purity of poetry, stripped of all superfluous wordiness.

As Willa Cather abandoned her journalistic activities and did not have to write to meet a dead-line, the word-for-word "borrowings" from earlier texts gradually disappeared. She continued, however, to use the same basic material several times in her fiction, revising and experimenting with effects by enlarging and diminishing scenes and incidents that turn up in slight disguises in story after story. Such is the case, for instance, with the campfire gatherings by a Western river, described with various changes in "The Treasure of Far Island" (1902), the opening poem of April Twilights (1903), "The Enchanted Bluff" (1909), Alexander's Bridge (1912), and My Antonia (1918). ${ }^{9} A$ similar scene is furthermore depicted in A Lost Lady (1923), introducing the main characters of that novel. The setting, atmosphere, and talk of the boys (and girls in My Antonia) are closely similar in the different works.

Incidents described in more than one story are most often inserted as asides, helping to give drama or color to a situation, or to give quick insights into the personality of minor, transient characters, such as the rich man cheating children in "The Treasure of Far Island," whom the protagonist describes as follows:

Next him sat the rich banker who used to offer the boys a quarter to hitch u p his horse for him, and then drive off, forgetting all about the quarter. (CSF, p. 271).

The tight-fisted nature of Cutter in My Antonia is illustrated in almost the same way:

If there were any boys about, Cutter would offer one of them a quarter to hold the stop-watch, and then drive off, saying he had no change and would "fix it up next time." (p. 211) 
In One \& Ours (1922), Claude Wheeler happens upon a poor, fatherless family, drifting about on the roads with no home of their own to return to. The mother is dying of consumption, and the children, although ill-fed and ill-dressed, are courteous, courageous, and prematurely dependable. Almost the same group, presented in a strikingly similar scene, first appeared in "El Dorado: A Kansas Recessional" (CSF, pp. 303-06).

Minor characters, especially, are sometimes easily recognizable from one story to another. Thus Lena Yensen in "On the Divide" (1896) has been considered a prefiguration of Lena Lingard in Mv Antonia; Peter Sadelack and his tragic life and death ("Peter," 1892) are again depicted as the Shimerda case in My Antonia. It also happens that major characters figure in more than one story. Nelly Deane ("The Joy of Nelly Deane," 1911) and her sad fate have been recognized in Lucy Gayheart, the protagonist in the novel of that name (1935). Rosicky ("Neighbour Rosicky" in Obscure Destinies, 1932) is generally regarded as an older version of Antonia's husband, Cuzac in My Antonia. As a rule, the second time Willa Cather presents a character, she treats it with more sympathy and warmth. Human frailties are depicted with gentle good humor instead of sarcasm or irony, a development which probably mirrors a mellowing of the author's personal attitude to life around her. ${ }^{10}$

The many characters in her fiction, based on the author as a girl, her father, or her youngest brother, do of course have a great deal in common, still they cannot be regarded merely as more or less elaborate copies of each other. Instead, they are wholly "independent" characters, because they are each made to represent different aspects of the personality that distinguished their prototype. Besides, the dramatic situations in which they are placed show rich variations. Their immediate surroundings, however, corresponding to the author's own background, are close to identical in such works as The Song $₫$ the Lark, "Old Mrs. Harris"(1931), and "The Best Years" (posthum.).

People, places and incidents in Willa Cathes's fiction have often been traced Sack to her own childhood experiences. It may be assumed that those that turn up several times in her writings had left impressions more indelibly inscribed in her mind than the rest; they kept surging to the surface of her consciousness, the same way Antonia did in Jim's thoughts. To apply to the author Jim Burden's words about Ántonia's powerful hold on his imagination, those experiences had left"images in the mind that did not fade- that 
grew stronger with time. In my memory there was a succession of such pictures, fixed there like the old woodcuts of one's first primer" (pp. 352-3). Such scenes and characters as recur in her works probably had for her, like Antonia had for Jim, "that something which fires the imagination" (p. 353).

Not always convinced that she had managed to convey to her readers the hidden meaning of certain things that seemed crucial to her, she had no choice but to try again. It took a great deal of experimenting sometimes before she could rest satisfied with the result.

\section{NOTES}

1 This essay came out simultaneously in the Nebraska State Journal (henceforth abbr. NSJ) and the Hesperian (a student publication) on March 1, 1891. It is reprinted in Appendix I to The Kingdom \& Art, ed. Bernice Slote (Lincoln, 1966; henceforth abbr. KA), pp. 422-25.

2 The italics in the quotations included in this essay are all mine. They mark word for word repetitions. My intention has been to make it easier for the reader to distinguish them from passages subjected to change. The article is reprinted in The World and the Parish, ed. William M. Curtin (Nebraska, 1970; henceforth abbr. $W \& P$ ), p. 422.

3 New Republic 30, April 12, 1922; reprinted in Not Under Forty (New York, 1936).

4 Reprinted in Collected Short Fiction 1892-1912, ed. Virginia Faulkner (Nebraska, 1963; henceforth abbr. CSF), pp. 425-39 and 359-79.

5 First published in NSF, Aug. 12, 1894, and the Library, July 7, 1900, respectively. Both articles reprinted in $W \Theta^{2} P$.

6 Courier, Feb. 17, 1900; reprinted in $W \& P$, p. 691.

7 References to the novels are to the Houghton Mifflin Co., Library Edition (Boston, 1937-1941).

8 NSF, April 28, 1895; reprinted in KA, p. 230-31, with a footnote by Bernice Slote, drawing attention to the similarity between the article and 'Eric Hermanson's Soul.'

9 Edith Lewis points out this fact in Willa Cather Living (New York, 1953), p. 171.

10 This change in attitude is clearly discernible in the unpublished letters I have read (at the Willa Cather Pioneer Memorial in Red Cloud, Nebr. and at the Clifton Waller Barrett Library, University of Virginia, Charlottesville, Va.), written to friends with whom the author corresponded during most of her adult life. 